\title{
THE STRATEGY OF NORTH SUMATRA PROVINCE BAWASLU IN PREVENTING VIOLATIONS OF ELECTION IN 2019 THROUGH SOCIAL MEDIA
}

\section{Farah Diba, Rifa Fachry, Gunawan, Nur Fadhil Muhammad, Annisa Khairuna, Muhammad Febrian, Fiki Alan Nuriansyah}

North Sumatra State Islamic University

dibaf873@gmail.com, rifafachry0@gmail.com,gnwn2006@gmail.com, muhammadsynurfadhil@gmail.com, annisakhairuna0321@gmail.com, goyentanju@gmail.com, fikialan85@gmail.com

\section{Abstract}

In the 2019 political year, social media has a very strategic role. In addition, the frequency of the emergence of hate speech and hoax news are even higher in the 2019 Election. Bawaslu as a supervisory institution has an important role to provide education to prevent election violations. So, in this study, researchers want to find out how the role and strategy of the Election Supervisory Body (Bawaslu) of North Sumatera Province prevent violations in the 2019 Election via social media. The formulation of the problem in this study is as follows: (1) What is the strategy of the North Sumatera Province Bawaslu in an effort to prevent violations of the 2019 Election via social media, (2) What is the role of the North Sumatera Province Bawaslu in an effort to prevent violations of the 2019 Election via social media.

The purpose of this study is to find out and understand what the strategy and role of the Bawaslu of North Sumatera Province in an effort to prevent violations of the 2019 General Election via social media. In this study, data processing and presentation is carried out using qualitative analysis techniques with research procedures that are to explain, manage, describe and interpret research results as a feature, character, or description of certain conditions, or phenomena as answers to the problems studied. Data collection techniques are in the form of observation, interviews, and documentation. This research uses democratic election theory, supervisory theory and institutionalism approach.

Key Word: Strategy, Bawaslu, Election, Social Media

\section{A. Introduction}

General Election, here in after referred to as Pemilu, is a means of people's sovereignty to elect members of the People's Representative Council, members of the Regional Representatives Council, the President and Vice President, and to elect 
members of the Regional People's Representative Council which are carried out directly, publicly, freely, confidentially, honestly and fairly. In the Unitary State of the Republic of Indonesia based on Pancasila and the 1945 Constitution of the Republic of Indonesia (UUD 2017: No 7).

Indonesia as one of the largest democracies in the world has stipulates six measures of democratic elections, namely direct, general, free, secret, honest and fair. This is contained in Article 22E paragraph 1 of the 1945 Constitution.

The Election Law and the election organizers that become its derivatives then add several more criteria such as being transparent, accountable, orderly and professional. Mass media is a means, channel, or media to communicate to the public. ${ }^{1}$

According to Cangara, media is a tool or means used to convey messages from communicators to audiences, while the notion of mass media itself is a tool used in delivering messages from sources to audiences by using communication tools such as newspapers, films, radio and television. ${ }^{2}$

This modern era is no something new for the world community in using mass media. Even the lives of today's people, especially urban communities, cannot be separated from the role of the mass media. The role of mass media in social life according to various literatures is unquestionable ${ }^{3}$. The mass media at this time has

\footnotetext{
${ }^{1}$ Roni,Tabroni. Komunikasi Politik Pada Era Multimedia. Bandung: Simbiosis Rektama Media,2012.

${ }^{2}$ Cangara, Hafied. Pengantar IImu Komunikasi. Jakarta: Rajawali Pers, 2010. hlm 123

${ }^{3}$ Ramlan, Surbakti. Memahami Ilmu Politik.Jakarta: Grasindo, 1992. hlm. 105
} 
grown rapidly, there are many influences that can be felt from the existence of the mass media on the lives of Indonesian people. Currently, many changes have occurred in Indonesian society which are influenced by the mass media.

Indonesian politics today is also influenced by the role of the mass media. Today, mass media plays a very important role in the political process ${ }^{4}$. The relationship between media and politics, especially the dependence between news sources and the press, can be said to be very interesting ${ }^{5}$. Basically, the mass media is used as a means of political communication. This communication takes the form of communicating information, ideas, emotions, skills, and so on by using symbols, words, pictures, numbers, graphics.

The advantage of social media is that the information is directly sent to the user, while having a wide reach. However, social media has a weakness, it's cannot correct/retract the information that has been disseminated, it allows irresponsible users to create fake accounts to spread false news and hoaxes, even during elections it can be used to target violent political opponents, know who the audience is, what is considered important and not important by the audience. In other words, it is necessary to explore the culture of the audience to be persuaded.

Political Year in 2019 , social media will play a very strategic role. In addition, the frequency of hate speech to hoax messages was even higher in the 2019 election.

\footnotetext{
${ }^{4}$ Ramlan, Surbakti. Memahami Ilmu Politik.Jakarta: Grasindo, 1992. hlm. 105

${ }^{5}$ Cangara,hlm:147
} 
Therefore, in this study the researcher wanted to find out through social media how the role and strategy of Bawaslu in preventing election violations in 2019.

\section{B. Research Method}

This research is a type of qualitative research. As stated above in this study, data processing and presentation is carried out using qualitative analysis techniques with research procedures that are to explain, manage, describe and interpret research results as a feature, character, or description of certain conditions, or phenomena in response to researched problem.

This study uses field research methods (field research). Field research is essentially a method to find out specifically and realistically what is happening at a time in the community. Field research generally aims to solve problems in depth about the background of the current situation, as well as the environmental interactions of a social group, individual, institution or community in everyday life. For this reason, researchers take steps, identify, collect, manage and review existing data, both in the form of primary data and secondary data, which of course are accurate and factual.

\section{General Election (Election)}

Based on the law, it is explained that General Elections called Pemilu are a means of people's sovereignty to elect members of the People's Representative Council, members of the Regional Representatives Council, President and Vice President, and to elect members of the Regional People's Representative Council, which are carried out directly, publicly, freely, and freely, confidential, honest, and fair in 
the Unitary State of the Republic of Indonesia based on Pancasila and the 1945 Constitution of the Republic of Indonesia (UUD RI, 2017: No 7). According to Ramlan Surbakti, general elections (Pemilu) are defined as a mechanism for selecting and handing over or handing over sovereignty to a trusted person or party ${ }^{6}$. Meanwhile, according to Ali Moertopo, elections are a means available for the people to exercise their sovereignty in accordance with the principles contained in the Preamble to the 1945 Constitution.

The above statement shows that elections are a means to achieve democracy. When people choose to elect their leader or representative according to laws and regulations as full ruler.

\section{Social Media}

Basically, social media is the latest evolution of new internet-based web technology, which makes it easy for anyone to communicate, join, share and network online to distribute their own content. Posts on blogs, tweets or YouTube videos are reproduced and viewable by millions of people who can watch them live for free. Social media are website-based features that form networks and allow people to interact with communities. On social media, you can interact, collaborate, and get to know each other in various ways, both in the form of written and audiovisual images. Social media examples are Twitter, Facebook, BlogSpot, Foursquare and others.

\footnotetext{
${ }^{6}$ Ramlan, Surbakti . Memahami IImu Politik.Jakarta: Grasindo, 1992. hlm.181
} 
The extent of the speed of social media which people can access has created an important information as the flow phenomenon not only in developed countries, but also in Indonesia as a developing country. The infect of social media's speed also seems to replace the traditional role of mass media in spreading news ${ }^{7}$.

The development of social media in cyberspace will continue to grow and keep growing. The ability to master and utilize it will become a strategic factor for political actors in the process of communication and his political campaign. Social media can have a positive effect on political actors by building intensive two-way political communication with supporters. Changes in mindset and mobilization of swaying voters' voices are also positive effects of social media.

\section{E. Bawaslu Regulations Regarding Social Media}

The lack of laws and election regulation that regulate the use of social media make Bawaslu enforces regulations with election participants, including MoUs with various social media platforms. Then cooperate with other government agencies. There is a Bawaslu Regulation Number 28 in 2018 regarding Campaign Monitoring and there are only regulations regarding the rules for campaign advertising on social media for campaign participants.

In carrying out the supervision of the Bawaslu of North Sumatra Province, it is not only cooperated with social media platforms, but also with the police and

\footnotetext{
${ }^{7}$ McQuail, Denis. Teori Komunikasi Massa Suatu Pengantar. Jakarta Erlangga, 1992, hlm..71
} 
prosecutors who are members of the Gakkumdu Center (Integrated Law Enforcement). Because the North Sumatra Province Bawaslu itself feels that it is still unable to handle several cases that occur related to social media due to the limited infrastructure it has.

\section{F. The Role and Strategy of the Election Supervisory Body (BAWASLU) of North Sumatra Province in Preventing 2019 Election Violations}

\section{a. Optimization of Surveillance on Social Media}

Basically, social media is the latest development of new internet-based web technologies, which makes it easier for everyone to communicate, participate, share and form an online network, so that they can disseminate their own content. How quickly people can access social media has resulted in a major phenomenon in the flow of information not only in developed countries, but also in Indonesia. Because of its speed, social media has also begun to appear to replace the role of conventional mass media in spreading news.

In this case, of course, the Bawaslu of North Sumatra Province uses social media as a means to assist in monitoring and preventing election violations. Bawaslu also cooperates with several parties related to social media, such as Facebook and Kominfo. So that when a violation is found, follow-up actions can be taken, such as account blocking. In addition, the Bawaslu of North Sumatra Province also provides education to the public to use social media wisely, in collaboration with Influencers. This is related to Lasswell's theory of political communication, which views that political communication is always value-oriented or trying to achieve goals. 
As an election supervisory agency, the North Sumatra Province Bawaslu certainly has an obligation to participate in providing education or insight to the public related to elections and the use of social media as an instrument in conducting supervision. So that Bawaslu can be more optimal in carrying out its supervisory function with participatory assistance from the community. Some of the steps or programs carried out by the Bawaslu of North Sumatra Province are as follows:

1. Cooperating with public figures/influencers

The Bawaslu of North Sumatra Province provides education to the public to use social media wisely, one of which is collaborating with public figures (Influencers).

2. Assisting the Discussion Forum and Cadre Schools.

The North Sumatra Provincial Bawaslu strives to foster the community and youth (students) to be equipped with understanding related to elections, therefore the North Sumatra Provincial Bawaslu often creates Discussion Forums with the community and holds Participatory Supervision Cadre Schools (SKPP) in various regions in North Sumatra. With the participatory supervision carried out by the community, it is hoped that it will help the performance of the Bawaslu of North Sumatra Province in supervising and preventing election violations. In addition, a cadre school and election observers are also formed under the official responsibility of Bawaslu in each Regency/City.

3. Collaboration with North Sumatra Province Bawaslu with External Parties 
In carrying out supervision to prevent, and take action against election violations, the Bawaslu of North Sumatra Province cooperates with relevant external parties. Due to the limitations of Bawaslu itself, it requires coordination with several institutions, such as the Police, the Prosecutor's Office, the Ministry of Communications and Informatics, and various social media platforms. In addition, the Bawaslu of North Sumatra Province also provides education to the public to use social media wisely, in collaboration with Influencers.

b. Benchmarks of the Effectiveness of Social Media in Assisting Monitoring

In this digital era, social media has become a trend in any communication. Social media is an online medium, with its users being able to easily participate and share. Of course, social media can be very effective in increasing supervision and community participation. Of course, the Bawaslu of North Sumatra Province will also optimize this. In carrying out the supervision of the Bawaslu of North Sumatra Province, it does not only cooperate with the social media platform, but also with the police and prosecutors who are members of the Gakkumdu Center (Integrated Law Enforcement). Because the Bawaslu of North Sumatra Province itself feels that it is still unable to handle several cases that occur related to social media due to the limited infrastructure it has.

Bawaslu is an election administrator who supervises and organizes the stages of the election, receives complaints, and handles administrative, criminal cases, election violations, violations of the code of ethics, and election disputes. The role of Bawaslu is 
to coordinate and monitor the stages of supervising the implementation of elections, receiving and following up reports on actions to conduct elections following up on recommendations and/or decisions of the Provincial Bawaslu and Regency/Municipal Panwas to the KPU regarding disruption of the election stages, and so on.

The presence of Bawaslu with its complete apparatus to the regional level is burdened with the hope that the supervisory function and contribution of election law enforcement will become more qualified, effective and efficient. With the independence of Bawaslu, strengthening the organization, and strengthening power, the public hopes that election violations can be prevented, election cases are handled, election disputes are resolved, and the election law is fully enforced ${ }^{8}$.

\section{G. Forms of 2019 Election Violations Found by Bawaslu of North Sumatra Province}

The 2019 Election Violations in North Sumatra were administrative violations. The number reached was 218 violations, it was followed by 57 violations of unknown type, 47 violations of money politics, and 37 violations of APK (Campaign Props) installation. Next, as many as 28 violations related to neutrality and violations of the code of ethics. A total of 27 violations were campaign organizing violations.

Then, there were seven violations related to BK (Campaign Material) spreading violations and 2 violations of abuse of office. Election administrative violations are

\footnotetext{
${ }^{8}$ Suswanto, Gunawan. Mengawal Penegak Demokrasi Di Balik Tata Kelola Bawaslu dan Dkpp.Jakarta: Erlangga,2016 hlm. 3
} 
violations that occur against procedures or mechanisms related to the administration of Pilkada implementation. Administrative violations do not include election crimes and violations of the code of ethics. There are two sources of alleged election violations, namely through findings and reports.

Based on the region, the Election Supervisory Body (Bawaslu) of North Sumatra Province received the most reports of violations of the 2019 Election, there were 47 violations, Central Tapanuli Regency Bawaslu followed with 45 reports of violations and Deli Serdang Regency Bawaslu with 34 reports of violations. Meanwhile, based on the reported party (reported), the majority of people who were reported to have committed Pilkada violations were Pilkada officers, namely 215 people. Followed by legislative candidates as many as 81 people and unknown as many as 68 people.

Provincial Bawaslu or Regency/Municipal Bawaslu must be accompanied and assisted by Election Crime Investigators and Prosecutors who are members of the Gakkumdu Center. Assistance includes identification, verification, and consultation on the reports/findings. Then the Election Supervisor, accompanied by members of the Gakkumdu Center, made clarifications to the reporters and witnesses who were present.

Each of these election violations was resolved by different institutions. The problem of administrative violations can be handled by Bawaslu, the problem of violating the code of ethics is handled by the DKPP, the problem of criminal offenses is 
resolved with Gakkumdu, while the problem of disputed election results can be resolved at the PTTUN/MA.

\section{H. Conclusion}

As an election supervisory agency, the North Sumatra Province Bawaslu certainly has an obligation to participate in providing education/insight to the public related to elections and the use of social media as one of the instruments for monitoring.

So that Bawaslu can be more optimal in carrying out its supervisory function with participatory assistance from the community. Several steps or programs carried out by the Bawaslu of North Sumatra Province are Collaborating with Public Figures/Influencers, Establishing Discussion Forums and Cadre Schools, and so on. 


\section{BIBILIOGRAPHY}

Amandemen Undang-undang Pilkada (UU No. 10 Tahun 2016)

Anwar, Ahmadi Muhammad. Prinsip-Prinsip Metodelogi Riset. Yogyakarta: Sumbangsih,1973.

Cangara, Hafied. Pengantar IImu Komunikasi. Jakarta: Rajawali Pers, 2010.

Henry Subiakto, Rachma Ida. Komunikasi Politik, Media \& Demokrasi. Jakarta: Kencana Prenanda Media Grup,2012.

McQuail, Denis. Teori Komunikasi Massa Suatu Pengantar. Jakarta Erlangga, 1992.

Moertopo, Ali. Strategi Politik Nasional. Jakarta: Centre for Strategic and International Studies (CSIS), 1974.

Ramlan, Surbakti . Memahami IImu Politik.Jakarta: Grasindo, 1992.

Roni,Tabroni. Komunikasi Politik Pada Era Multimedia. Bandung: Simbiosis Rektama Media,2012.

Suswanto, Gunawan. Mengawal Penegak Demokrasi Di Balik Tata Kelola Bawaslu \&Dkpp.Jakarta: Erlangga,2016. 